\title{
KOMIK SEBAGAI WAHANA PENDUKUNG PROSES PENDIDIKAN ANAK
}

\author{
Oleh: Esti Swatika Sari
}

\begin{abstract}
Abstrak
Komik merupakan salah satu jenis karya sastra (khususnya sastra anak) yang mampu berperan dan diperlakukan sebagaimana layaknya sebuah karya sastra. Dikatakan demikian, karena pada dasarnya komik terdiri atas bahasa-gambar-teks. Hal ini sesuai dengan pengertian yang lebih luas mengenai literature yakni sebagai bahasa yang diungkapkan dengan tulisan.

Adanya komik sebagai salah satu bacaan anak-anak ternyata tidak hanya sekedar dinikmati gambarnya atau digunakan sebagai hiburan, tetapi lebih jauh mampu memberikan interpretasi dan penilaian terhadap peristiwa dalam kehidupan. Layaknya cerita anak, komik sebagai salah satu karya fiksi ternyata mempunyai andil dalam proses pembentukan diri anak. Komik secara tidak langsung ikut mempengaruhi emosi dan rasa simpati dalam diri mereka. Daya bangun dan kreasi imajinasi anak muncul dan berkembang mengikuti jalan cerita yang disajikan. Oleh karena itu, meskipun pengarangnya adalah orang dewasa, penyajian ceritanya tetap disesuaikan dengan alam pikiran anak-anak, yaitu dengan menggunakan bahasa anak-anak yang tentunya sesuai juga dengan alam imajinasi mereka. Sastra tidak lahir dari kekosongan budaya. Ada latar belakang dimunculkannya sebuah karya sastra. Begitu juga dengan komik, walaupun dilihat dari bentuknya hanya terdiri dari gambar dan teks, tetapi ada unsur-unsur fiksi terdapat di dalamnya seperti adanya tema, tokoh, latar, dan ada amanat yang ingin disampaikan pengarangnya sehingga pemahaman dan pemaknaan terhadapnya mampu memberikan manfaat bagi pembacanya yang terwujud dalam bentuk nilai-nilai (khususnya yang mendukung pembentukan dan perkembangan kepribadian anak) dan akhirnya mendukung proses pendidikan anak.

Nilai-nilai pendidikan dalam komik (sebagai bacaan sastra anak-anak) secara garis dapat dijelaskan melalui percakapan antartokoh, tema, pemakaian bahasanya, dan penyajian bentuk gambar yang digunakan. Dalam upaya merealisasikan komik sebagai bacaan sastra anak-anak, perlu adanya pengenalan dan pemakaian bacaan komik sejak dini, yaitu tingkat taman kanak-kanak dan sekolah dasar. Di samping itu bimbingan dari orang tua juga harus dan tetap ada. Bagaimanapun juga rasio berpikir anak secara nyata masih kurang dibanding dengan daya imajinasi mereka, karena pada usia kanak-kanak pengetahuan mengenai adanya hal-hal dalam kehidupanyang sifatnya nyata dan masuk akal
\end{abstract}


dalam pikiran mereka masih sedikit. Oleh karena itu, perlu ada pemilihan tema komikyang sesuai dengan umur serta perkembanganjiwa mereka.

\section{A.Pendahuluan}

Pendidikan merupakan hal yang sangat penting bagi setiap manusia karena membantu kehidupan yang dijalaninya menjadi lebih baik. Dalam berbagai segi kehidupan, manusia selalu memerlukan cara untuk menjalani hidupnya agar segala sesuatu yang menjadi tujuan hidupnya akan dapat tercapai. Pendidikan yang dimaksud di sini tentu saja tidak terpaku hanya pada satu bidang ilmu atau lebih seperti yang diajarkan di sekolah-sekolah, tetapi lebih luas dari itu. Banyak hal yang tidak didapat secara mendetail di sekolah, misalnya mengenai budi pekerti, bagaimana seharusnya hidup di lingkungan masyarakat dengan baik, bertutur sapa yang ramah, dan bagaimana menyelesaikan suatu masalah atau menghindarinya. Contoh tersebut hanya merupakan sebagian kecil dari sekian banyak dinamika kehidupan yang nantinya akan dijalani dan dilalui oleh anak-anak. Dunia anak-anak identik dengan kepolosan, keluguan, apa adanya. Hal ini tentu saja wajar, walaupun terkadang ada hal-hal yang muncul begitu saja dan tidak mampu dimengerti oleh anak yang kemudian membuat mereka menjadi terpengaruh padahal mungkin hal itu tidak baik. Bisa juga karena terlalu sering anak membaca komik, dia menjadi lupa terhadap kewajibannya, yaitu belajar. Akan lebih baik jika bacaan yang diberikan justru ikut mendukung proses belajar anak, misalnya sekarang banyak diciptakan buku cerita tetapi isinya mengandung satu bidang pelajaran seperti matematika. Anak akan lebih tertarik kepada halhal yang sifatnya baru bagi mereka. Jika cara berhitung disajikan dalam sebuah cerita atau komik, jelas menarik perhatian anak-anak. Tujuan yang didapat dari proses pendidikan bukan hanya untuk membuat anak menjadi pandai, tetapi juga membuat diri anak menjadi baik. Jadi, bukan hanya kecerdasan yang akan ditingkatkan, tetapi kepribadian juga akan dibentuk dan dikembangkan menjadi lebih baik. Ada keseimbangan antara jasmani dan rohani, fisik dan psikisnya.

Pendidikan itu sendiri tidak mengenal umur, jenis kelamin, status sosial, dan hal-hal lainnya. Selama manusia masih hidup, dia akan terus memerlukan pendidikan. Cara mendapatkan pendidikan tidaklah sulit, saja. 
bergantung pada individu masing-masing. Pendidikan dikatakan mudah didapatkan karena hal ini tidak terpaku hanya pada pendidikan formal di sekolah saja. Akan tetapi, masih ada pendidikan nonformal di luar sekolah. Berbicara lebih jauh mengenai cara medapatkan pendidikan, sebenarnya sejak manusia dilahirkan dia sudah mulai mendapatkannya. Bagaimana proses pembentukan dan perkembangan anak sejak bayi hingga menjadi besar; menjadi yang baik atau tidak, mempunyai etika atau tidak, beragama atau tidak dan masih banyak lagi. Selama proses tersebut masih menyangkut diri manusia secara utuh (lahiriah dan batiniah), hal itu dapat dinamakan sebagai proses pendidikan.

Di dalam proses pendidikan yang berlangsung itulah, dihasilkan nilai-nilai pendidikan yang berperan sebagai subyek yang secara tidak langsung mencoba "mempengaruhi" (baca:memasuki) diri manusia sebagai obyek. Hal ini berlaku mulai masa kanak-kanak. Nilai-nilai pendidikan ini sangat beragam, ada yang umum dan juga ada yang khusus, artinya nilai pendidikan yang didapatkan bukan hanya melalui pengajaran di sekolah atau pengarahan di keluarga, tetapi ada juga yang didapatkan sendiri, misalnya dari pengalamannya membaca banyak buku. Apa pun bentuk dan bagaimana cara memperolehnya yang jelas masih berkaitan erat dengan proses pembentukan kepribadian manusia. Seperti nilai etika, nilai moral dan agama, nilai budi pekerti, dan lain sebagainya. Hal ini berlaku bagi semua manusia, tidak terkecuali anak-anak. Justru pada masa kanak-kanak, proses pendidikan sudah harus diperhatikan dengan baik, karena alam berpikir anak masih sangat baru dan masih sangat awam dengan kehidupan yang sesungguhnya. Mereka masih asyik dengan sifat kebocahannya sehingga perlu diarahkan ke tujuan mana anak nantinya dapat menjadi manusia yang baik.

Peran orang tua, guru, dan orang-orang yang ada di sekitarnya sangat berperan dalam hal ini. Selain itu keadaan lingkungan, baik itu keluarga, sekolah, dan masyarakat juga ikut berpengaruh. Apalagi jika anak dibiarkan menjalani hidupnya tanpa bimbingan yang intensif, akan mungkin anak menjadi bukan dirinya. Hal itu mungkin terjadi mengingat sekarang sepertinya tidak ada filter atau seleksi terhadap hal-hal yang diserap oleh anak-anak, misalnya tayangan televisi dan bacaan anak-anak. Perlunya arahan dan masukan mengenai yang benar dan salah, yang baik dan buruk harus sering dilakukan oleh orang tua dan guru, agar apa yang mereka lihat, 
baca, dan dengar dapat jelas dipahami oleh anak-anak.

Semua hal di atas dipandang perlu karena dari sekian banyak aktivitas yang dilakukan oleh anak-anak, membaca komik adalah kegiatan yang paling disukai oleh anak-anak selain sekolah dan belajar, apalgi jika anak sudah melek huruf. Menurut Sugiharti (1997:46) pada usia 10 tahun ke atas, 100\% anak lebih suka membaca setelah daripada bermain, dan pada usia 7-10 tahun, sekitar 35,78\% lebih suka membaca daripada bermain.

Salah satu nilai pendidikan tersebut adalah nilai pendidikan dalam karya sastra (artinya nilai pendidikan yang diperoleh dengan membaca karya sastra), karena ada pengertian tersendiri yang membedakannya dengan nilai pendidikan pada umumnya. Banyak karya sastra yang telah ada dan dipelajari, seperti prosa fiksi (novel, cerpen), puisi, dan drama yang tidak hanya sebagai bacaan hiburan di waktu senggang, tetapi juga telah mampu mempengaruhi pikiran dan emosi pembacanya. Kemudian secara tidak langsung ikut berperan dalam kehidupan pembacanya. Seperti yang dikatakan Widyastuti Purbani dalam makalahnya yang berjudul "Beri Mereka Sayap" (2000:1-2) bahwa karya sastra sejak beratus tahun lamanya terbukti memliki potensi dan daya yang besar untuk 'mendidik' dengan cara yang lebih halus, bahkan bawah sadar. Karya sastra yang baik memiliki kandungan pengetahuan 'keras' maupun 'halus' mengenai hidup dan kehidupan manusia, pengalamanpengalaman khusus manusia, penjelasan tentang makna hidup, religiusitas, tatanan dan norma kehidupan yang penting diketahui oleh anak-anak dalam masa awal kehidupan mereka. Pengetahuan 'keras' adalah fakta atau data mengenai kehidupan manusia tersebut di atas, sedangkan pengetahuan 'halus' adalah pengetahuan mengenai hati nurani manusia. Tentunya menjadi semakin jelas bahwa keterlibatan karya sastra dalam proses pembentukan kepribadian anak sudah mendarah daging, menjadi semacam faktor sekunder tetapi sangat diperlukan.

Ketiga jenis karya sastra tersebut sudah biasa ada di lingkungan pembaca. Bahkan, terkadang mereka menginginkan bentuk yang lain. Bentuk yang lain ini menjadi semacam 'menu tambahan' bagi anak; ketika anak bosan dengan 'menu utama' maka dicarilah 'menu tambahan' tersebut dan tentunya 'menu' ini mempunyai manfaat yang mendukung dari 'menu utama'. Salah satu bentuk 'menu tambahan' yang sedang digemari oleh anak-anak adalah komik. Walaupun pemunculan komik sudah sejak abad ke-19 di negara-negara Barat

DIKSI, Vol.8 No.19 Januari 2001 
(Kurt \& Meirer, 1986:69), sampai kemunculannya di Indonesia tidak diketahui, tetapi komik masih difungsikan sebagai bacaan hiburan saja. Padahal, sebagian besar komik yang diminati anak-anak adalah terjemahan dari negara lain, seperti Jepang, Amerika, Perancis, dan sebagainya yang tentunya latar belakang diciptakannya komik juga berbeda dengan latar belakang kita. Pemilihan komik dan dampingan orang tua ketika anak membaca komik menjadi sangat dibutuhkan supaya anak tidak begitu saja menyerap hal-hal yang dapat mereka dapatkan dari komik. Bagaimanapun juga banyak yang bisa didapatkan dari bacaan ini, bukan hanya sebatas hiburan, akan tetapi ada nilai-nilai pendidikan bagi anak. Hal inilah yang menjadi dasar bagi komik sebagai bacaan sastra anak-anak sejak dini dan dapat dijadikan bahan dalam dunia pendidikan.

\section{B. Komik Anak Sebagai Bacaan Sastra Anak}

Komik dikatakan merupakan bacaan sastra anak-anak karena adanya pengertian yang lebih luas mengenai literature, yaitu sebagai bahasa yang diungkapkan dengan tulisan. Media komik itu sendiri terdiri atas bahasagambar-teks (Kurt \& Meier, 1986:68). Jadi pada dasarnya komik merupakan cerita bergambar disertai sedikit teks yang biasa ditulis dalam suatu gelembung. Komik terdiri atas visual dan verbal, akan tetapi dalam kehadirannya didominasi oleh aspek visual karena komik lebih menampilkan gambar daripada teks. Jadi, seluruh teks dalam komik merupakan susunan hubungan antara bentukan yang berupa bahasa dan gambar menjadi satu kesatuan yang tidak dapat dipisahkan. Bahasa dalam komik biasanya berupaka kalimat langsung didukung dengan cara penyampaiannya dalam bentuk dramatik. Isi ceritanya sendiri disajikan dalam penataan gambargambar tungal suatu urutan. Munculnya komik diawali pada abad ke-19 yang semula hanya sebagai cerita bergambar dalam pengertian yang luas, kemudian mengalami perkembangan dari jaman ke jaman dan dari waktu ke waktu sampai diwujudkannya gambar-gambar secara serial tersebut di koran Minggu Harian New York Herald di Amerika Serikat untuk pertama kalinya. Setelah pemunculan perdana terbitan serial komik tersebut, lalu muncul komik-komik lain dengan beragam isi, ada yang lucu, ada juga yang bersifat politis-satites (mengejek atau mengkritik keadaan politik) Kemudian karena suksesnya penerbitan tersebut, maka diciptakanlah "buku komik". Ciptaan ini 
selain memperluas media juga memperluas temanya menjadi tema petualangan, fantasi, ataupun kriminal.

Pada saat Perang Dunia II, komik semakin mendunia dan digemari oleh masyarakat. Ketika pertama kali muncul adalah untuk menghibur tentara Amerika yang sedang berperang, tema yang dipakai adalah seks dan kriminal. Dari tema inilah timbul ketakutan akan pengaruhnya yang tidak baik terhadap pembaca, akibatnya tema komedi atau humor menjadi alternatif lain dan penyebarannya menjadi semakin meluas, seperti dijelaskan lebih lanjut oleh Herald Vogel (lewat Kurt \& Meier, 1986) bahwa komik ada beberapa macam, yaitu:

1. Komik kocak yang berisi hal-hal yang lucu, penuh humor

2. Komik petualangan yang berisi petualangan dalam rimba, padang rumput, kejahatan, percintaan, menegangkan dan menakutkan

3. Komik fantasi yang isinya fiksi dalam ilmu pengetahuan, teknik dan dongen

4. Komik sejarah atau historis yang berisi hal-hal yang yelah dicapai atau dianggap sebagai sejarah

5. Komik nyata atau klasik yang menceritakan kembali dengan gambar dan teks-teks karya literer terkenal

Akan tetapi, menurut penelitian yang dilakukan oleh H.D. Zimmerman (lewat Kurt \& Meier, 1986) frekuensi jenis komik lucu lebih disukai pembaca dengan rata-rata $64,2 \%$.

Sesuai dengan pernyataan bahwa komik merupakan hasil karya sastra, maka komik juga mempunyai struktur tertentu. Ada temanya yang sangat beragam, ada jalan cerita, tokoh, latar, dan ada juga pesan-pesan yang mengandung nilai-nilai tertentu. Akan tetapi melihat pemunculannya yang bervariasi dengan tema yang berkembang, maka komik juga dapat berfungsi lain karena sudah menyangkut pikiran dan emosi pembacanya, artinya fungsi komik lebih jauh dapat ikut berpengaruh terhadap kehidupan anak. Hal tersebut mungkin terjadi karena ketika membaca, anak akan melakukan interpretasi dan penilaian terhadap bacaanya. Sesuai dengan perkembangan tema komik, kalangan pembacanya juga ikut berkembang, artinya yang dulunya hanya kalangan prajurit, berkembang sampai di kalangan anak-anak.

DIKSI, Vol.8 No.19 Januari 2001 
Bahkan dikatakan oleh Kurt \& Meirer (1986:67) bahwa 90\% pembaca komik adalah pelajar. Jenis komiknya pun sudah sangat beragam dari action sampai komedi. Komik yang paling disukai adalah komik bertema komedi dan yang berasal dari negara Jepang sekitar $64 \%$ (Sugiharti, 1997:45). Hal ini didukung juga oleh Sarumpaet (1977:42) yang menyebutkan juga bahwa komik yang paling disukai anak-anak adalah komik yang berasal dari Jepang. Jelasnya sejak komik mulai disukai anak-anak, pemunculan tema komik biasanya menyajikan hal-hal yang sesuai dengan alam hidup anak, misalnya petualangan, kepahlawanan, atau kisah sehari-hari. Selain itu dalam penceritaan menggunakan gaya langsung dan tidak berbelit-belit. Seperti yang dikatakan oleh Wellek dan Warren (1995:109) bahwa sastra menyajikan kehidupan, dan kehidupan sebagian besar terdiri atas kenyataan sosial.

Dunia anak identik dengan dunia kegembiraan, dunia tawa tanpa persoalan. Lebih lanjut Sarumpaet menjelaskan bahwa anak-anak lebih menyukai komik terjemahan dari Jepang karena lebih mudah untuk dipahami ceritanya dan ilustrasi gambarnya lebih menarik dibanding dengan komik lain, termasuk yang berasal dari negeri sendiri (Indonesia), walaupun tidak menutup kemungkinan bahwa komik yang berasal dari negara Perancis atau Amerika, seperti Felix Obelix, Donald Bebek, Dragon Ball, Asterik, Sailor Moon, Mickey Mouse juga digemari oleh anak-anak. Bagaimanapun juga bukan darimana komik itu berasal, tetapi bagaimana pemahaman anak terhadap isi cerita komik itu yang perlu lebih diperhatikan. Persoalan isi cerita dan tampilan ilustrasi gambar ini menjadi sangat penting, karena masa kanakkanak merupakan masa saat anak-anak baru mengenal dan mempunyai fantasi serta imajinasi yang besar. Mereka hanya peduli sesuatu itu menarik atau tidak, bukan bagaimana sesuatu itu terjadi. Mereka hanya mengerti cara menikmati dan mulai membangun imajinasi atas apa yang dinikmatinya, sedangkan hal lainnya yang masih berkaitan dengan bagaimana kenikmatan tersebut terjadi tidak akan terlintas di benak mereka. Jika boleh dikatakan, masa kanak-kanak adalah masa keluguan dan apa adanya. Akan tetapi mereka dapat menikmatinya dengan daya imajinasi mereka sendiri, karena pada masa kanak-kanak ini imajinasi anak sudah mulai tumbuh. Begitu juga saat anak membaca komik, mereka akan cenderung memilih komik yang berpenampilan menarik dengan ilustrasi gambar yang bervariasi dan cerita yang mudah ditangkap serta dipahami oleh anak-anak, misalnya komik Dora 
Emon. Komik ini bertema humor dengan penampilan ilustrasi gambar yang menarik dan mendukung isi cerita serta mudah dipahami oleh anak.

Norman Podhirets (lewat Suharianto, 1977:8) menyatakan bahwa sastra dapat memberi pengaruh yang sangat besar terhadap cara berpikir seseorang mengenai hidup, mengenai baik dan buruk, mengenai benar dan salah, mengenai cara hidup sendiri serta bangsanya. Sama dengan dengan komik, selain sebagai bacaan penghibur, komik juga dapat dijadikan sarana untuk mengasah emosi dan rasa simpati dalam jiwanya. Fungsi komik di sini sudah menjadi fungsi edukatif karena salah satu fungsi komik adalah edukatif,artinya mampu memberikan nilai pendidikan bagi pembacanya. Emosi adalah perasaan, gerak hati, serta pengamatan mereka akan imajinasinya. Ketika membaca komik, secara tidak sadar emosi mereka mulai muncul. Wujud reaksi emosional ini dapat berupa gerak tangan, mimik bibir, dan raut wajah. Bahkan tidak jarang ada yang melontarkannya dengan katakata, kadangkala disertai dengan tetes air mata jika ceritanya sedih, atau mungkin dengan tertawa terbahak-bahak karena ceritanya lucu. Luapan emosi ini biasanya dibangkitkan oleh segala sesuatu yang ada dan menonjol dalam cerita itu, misalnya sifat dan perilaku tokoh yang memperkuat dan mempertajam imajinasinya. Begitu juga dengan rasa simpati yang lebih ditekankan pada perasaan turut merasakan penderitaan orang lain dan peka terhadap nasib serta keadaan orang lain. Anak akan dapat merasakan apa yang dirasakan oleh orang lain, mereka akan mengembangkan kepekaan terhadap keadaan orang lain. Mungkin dengan berdiam diri atau dengan mengekspresikan mimik wajahnya atau dengan gerakan-gerakan yang tidak menentu, tidak ada artinya, tetapi dapat juga berupa perbuatan yang dapat menolong orang lain membebaskan diri dari tekanan. Rasa simpati ini merupakan salan satu bentukan dari emosi jiwanya. Kemunculannya juga karena adanya segala sesuatu yang ada dalam cerita dan yang memperkuat serta mempertajam emosinya. Di sinilah letak peran komik dalam membantu proses pendidikan anak. Melalui tokoh-tokoh dengan segala sifat dan perilakunya, koflik-konflik yang dimunculkan, penyelesaiannya, dan juga ilustrasi gambar yang ditampilkan yang setidaknya ikut berpengaruh ketika anak membaca komik. Ilustrasi gambar membantu anak dalam membangu imajinasinya ketika membaca komik.

Dilihat dari intensitas membacanya, maka komik jelas sudah ikut 
mempengaruhi diri anak karena dengan intensitas membaca yang sering, pemikiran anak akan terpengaruh oleh nilai-nilai atau pesan-pesan yang didapat dari komik yang dibacanya. Selain itu juga mampu menumbuhkan kecintaan dan minat baca anak terhadap sastra dan karya sastra yang ternyata ikut berperan dalam pembentukan diri anak. Oleh karena itu komik sudah berfungsi edukatif, artinya mampu memberikan nilai pendidikan bagi pembacanya (Kurt \& Meier, 1986:73). Pembaca (dalam hal ini anak-anak) diharapkan mampu memahami isi komik dengan baik, karena ada hal positif dan negatif yang dapat diambil dari bacaan ini. Ada bermacam pengetahuan yang bisa diambil dengan membaca komik antara lain bagaimana cara memecahkan masalah dengan baik, menjaga diri, mencari kesenangan, kebebasan, bersosialisasi yang baik, dan beragama yang baik. Jelasnya tema komik disajikan seperti karya sastra lainnya, yaitu masih mengacu pada kehidupan manusia secara universal dan tentunya sesuai dengan alam kehidupan anak-anak.

\section{Nilai Pendidikan Dalam Komik}

Nilai pendidikan dapat dikatakan sebagai pesan atau sesuatu yang ingin disampaikan sebagai proses pengubahan sikap dan tingkah laku seseorang. Hal ini dapat berupa ajaran moral, budi pekerti, dan nilai ketakwaan. Dalam hal ini yang ingin menyampaikan pesan secara tidak langsung adalah komik. Komik merupakan salah satu bacaan anak-anak, di dalamnya berisi cerita yang berkaitan erat dengan dunia anak-anak. Sebagai cerita anak-anak, idealnya harus mencerminkan tingkat intelektualitas dan daya imajinasi anak-anak serta mengikuti selera anak-anak. Maka dari itu cerita anak-anak tidak dapat jauh berbeda dari jangkauan daya ikir dan daya kreasi imajinasinya. Perwujudan cerita anak sebagai media seni dalam mengekspresikan diri anak adalah dengan memperhatikan bahasanya. Bahasa secara umum adalah alat komunikasi. Akan tetapi tidak selamanya dapat dipahami, tergantung pemakai dan komunitasnya. Bagaimanapun juga bahasa tidak hanya sekedar ujaran yang dilafalkan, tetapi ada maksud yang ingin disampaikan. Oleh karena itu dalam cerita anak-anak, bahasa yang digunakan juga harus sesuai dengan bahasa anak-anak. Bahasa cerita anak merupakan wujud dari sebuah proses dialektik yang bertolak dari idiom dunia berpikirnya dalam usaha dan perjalanannya menjadi orang dewasa (Sugihastuti, 1996:70).

Komik sebagai Wahana...(Esti Swatika Sari) 
Tentunya hal tersebut dimaksudkan agar cerita yang disajikan lebih mudah dipahami oleh pembaca (anak-anak), meskipun pengarangnya orang dewasa. Dari pemakaian bahasa anak-anak sebagai alat komunikasi dalam cerita anak inilah akhirnya ada hal-hal yang dapat diserap oleh anak-anak, tidak hanya sekedar membolak-balik halaman, tetapi akan lebih ikut merasakan dunia dalam cerita itu; mungkin akan tertawa kalau lucu, menangis kalau sedih, berteriak dan mengumpat kalau kesal, mengeskpresikannya dengan gerakan-gerakan tertentu sesuai dengan daya bangun imajinasi anak. Sampai akhirnya di luar kesadaran mereka, hal itu sudah membantu proses pengembangan diri mereka. Ada kesan-kesan khusus yang dirasakan oleh anak yang akhirnya akan diingat dan dibawanya dalan dunia mereka yang sesungguhnya. Kesan-kesan ini merupakan wujud dari keberterimaan anakanak terhadap pesan-pesan yang dapat mereka ambil dari cerita yang mereka baca. Kesan dan pesan tersebut jika dapat kita katakan adalah nilai-nilai yang dapat diambil dari sebuah cerita anak dan secara tidak langsung ikut mempengaruhi perkembangan diri anak.

Nilai-nilai pendidikan dalam komik adalah nilai-nilai pendidikan dalam karya sastra. Menurut Shipley lewat Tarigan, 1988:19, suatu karya sastra pada umumnya memiliki nilai hedonik yang dapat memberikan kesenangan secara langsung, nilai artistik yang memanifestasikan keterampilan seseorang, nilai kultur yang mengandung hubungan dengan masyarakat dan kebudayaan, nilai etis dan moral serta nilai religius jika di dalamnya terkandung ajaran-ajaran yang berkaitan dengan etika, moral dan agama. Kemudian nilai praktis jika di dalam karya sastra itu terkandung halhal yang dapat dilaksanakan dalam kehidupan sehari-hari (Tarigan, 1988:194). Jadi, nilai pendidikan dalam sastra adalah nilai pendidikan dan ketaqwaan kepada Tuhan, budi pekerti, berkepribadian, tanggung jawab, kemandirian, kecerdasan, ketrampilan, nilai hedonik,kultural dan praktis serta nilai estetis. Begitu juga dengan nilai-nilai pendidikan yang terdapat dalam komik yang tidak jauh berbeda dengan nilai pendidikan dalam sastra karena komik juga merupakan karya sastra, antara lain nilai moral dan etis, nilai kepribadian, nilai kecerdasan, nilai kritis, nilai hedonik, nilai praktis, nilai religius, dan nilai esetetis. Nilai-nilai pendidikan ini tercermin dari interaksi antartckoh, tingkah laku, dan gambaran peristiwa termasuk pemakaian bahasa dan penyajian gambarnya. Isi cerita jelas berpengaruh

DIKSI, Vol.8 No.19 Januari 2001 
terhadap daya imajinasi anak. Di samping itu ilustrasi gambarnya ikut mendukung isi ceritanya, karena ilustrasi yang baik adalah ilustrasi yang mempunyai daya pesan dan imajinasi yang sesuai isi cerita dan mengenai sasaran. Ilustrasi yang mengenai sasaran merupakan wujud telah sampainya pesan cerita kepada pembaca (Sugihastuti, 1996:75). Selain itu juga ilustrasi gambarnya merupakan cerminan dari munculnya nilai keindahan.

Untuk lebih jelasnya kita lihat beberapa contoh dialog dalam komik di bawah ini yang menyiratkan adanya nilai pendidikan tertentu:

$$
\begin{aligned}
& \text { Ibu : Nobita, bohlamnya putus! Tolong belikan!!! } \\
& \text { Nobita : Aku sedang belajar! (padahal hanya pura-pura) } \\
& \text { Ibu : Disuruhorang tua merupakan pendidikanjuga! }
\end{aligned}
$$

Nobita : Ke toko lsitrik'kan harus menyeberang perseimpangan rel keretaapi,jauh'kan!

Kedua contoh di atas menyiratkan adanya unsur nilai moral dan etika. Saat orang tua menyuruh anaknya, bahkan dengan kata 'tolong', tentunya merupakan hal yang harus dipatuhi selagi hal itu masih wajar. Mengesampingkan rasa individualis demi menyenangkan hati orang tua merupakan perbuatan yang terpuji. Moral dan etika anak sudah dapat kita latih dan kita bentuk sejak anak mulai mengenal lingkungan. Oleh karena itu, orang-orang dan lingkungan yang ada di sekitarnya hendaknya mempunyai batasan tersendiri mengenai hal-hal yang baik atau tidak dan arahan dari orang-orang yang lebih tahu dari mereka juga sangat diperlukan. Jika mulai dari masa kanak-kanak saja sudah mulai tidak mematuhi orang tua, apalagi jika besar nanti.

$$
\begin{aligned}
& \text { Ibu :Ayahtadilupabawadokumen penting! } \\
& \text { Nobita : A...akumautidur siang! Eh bukan, banyak PR! } \\
& \text { Ayah : Bukuyangdibelitahun lalu sudahdibacabelum? } \\
& \text { Nobita : Buku? Oh, yang isinya huruf semua itu? Tentu saja sudah } \\
& \text { dibaca.. }
\end{aligned}
$$


Kedua contoh di atas menggambarkan anak yang suka berbohong. Kejujuran adalah cerminan dari nilai kepribadian yang didukung oleh nilai keagamaan. Apa pun alasannya, kebohongan adalah hal yang tidak boleh dilakukan, selain berdosa juga mencerminkan pribadi yang tidak baik. Pembentukan kepribadian yang diwarnai dengan nilai seperti ini, akan membentuk pribadi anak menjadi tidak lebih baik. Belajarlah jujur untuk hal sekecil apa pun karena kejujuran adalah kunci keberhasilan. Dalam agama pun berbohong adalah hal yang dilarang karena berdosa.

Nobita : Kenapa selalu aku yang... Nggak ada satupun yang baik untukku.

Nobita : Hidup ini takmenyenangkan!!!

Nobita : Kenapabadankubeginipendek???

Kutipan di atas menggambarkan bahwa kadang anak lupa untuk selalu mensyukuri apa saja yang diberikan oleh Tuhan. Syukur berarti mengucapkan terima kasih, dalam hal ini ditujukan kepada Tuhan. Syukur atas nikmat yang diberikan Tuhan adalah berterima kasih dalam bentuk ucapan dan perbuatan (Nurdin dkk, 1993:244). Bersyukur merupakan hal yang sangat terpuji karena orang yang melakukannya berarti telah menerima apa adanya segala sesuatu yang diberikan padanya.

\section{Nobita : Hai Suneo, di hari Natal ini kamu bisa mendapatkan barang yang kamumau? \\ Suneo :Apapun keinginanku pastidikabulkan, keluargaku'kan kaya raya!}

Kekayaan dicari bukan untuk dipamerkan apalagi menyombongkan diri karena dia kaya. Semuanya diberikan Tuhan bukan untuk dibandingkan den gan yang lain. Kekayaan bukanlah segala-galanya, ada hal-hal yang tidak bisa dibeli dan didapatkan dengan kekayaan, misalnya mendapatkan teman baik. Sifat sombong muncul ketika anak merasa dirinya selalu lebih dari anak

DIKSI, Vol.8 No.19 Januari 2001 
yang lain. Tentunya sifat ini tidak diharapkan ada dalam pribadi anak.

\author{
Nobita : Apaitu,...suara eranganyang menyakitkan teliga! \\ Ayah : Didalam hati ayah, kartu abjad dan radio kontrol tengah \\ bertempur dengan sengit \\ Nobita : ....sepertidimasukkan dalam batubara
}

Pemakaian majas personifikasi dan simile digunakan oleh pengarang untuk lebih memunculkan nuansa keindahan atau nilai esetetika. Ada juga penyajian onomatope atau tiruan bunyi yang sengaja digunakan untuk lebih menekankan pada suatu kejadian tertentu, misalnya suara BRUGH digambarkan sebagai bunyi orang jatuh, DRAT DRAT sebagai bunyi derap kaki kuda, SRUP SRUP sebagai bunyi orang makan mie, BONK sebagai bunyi orang yang menabrak pintu dan lain sebagainya. Penyajian onomatope ini ditampilkan juga dalam tiga bentuk, yaitu (1) berhuruf biasa, (2) berhuruf tebal, (3) berhuruf besar dan kecil. Khusus yang berhuruf tebal dimaksudkan untuk melambangkan kekuatan bunyi yang ditimbulkan apalagi jika hurufnya besar berarti bunyinya sangat keras. Selain itu penampilan setting, tokoh, peristiwa-peristiwa juga dilukiskan dengan sangat menarik dan juga gelembung bicara yang dilukiskan bermacam-macam.

Semua contoh di atas hanya merupakan sebagian kecil dari bacaan komik, dan itu sudah banyak menunjukkan bahwa komik tidak sekedar sebagai bacaan hiburan tetapi juga ada nilai-nilai pendidikan yang dapat dijadikan aspek pendukung bagi proses pendidikan anak.

\title{
D. Upaya Merealisasikan Komik Sebagai Wahana Pendukung Proses Pendidikan Anak
}

Kenyataan bahwa komik bukan lagi bacaan anak yang sekedar mampu memberikan hiburan bagi pembacanya harus segera disadari. Ada nilai-nilai pendidikan yang mampu dimunculkan dari sebuah komik. Tentunya tidak semua contoh-contoh yang diceritakan baik untuk ditelan mentah-mentah oleh anak-anak, artinya ada contoh yang baik dan ada juga yang buruk. Bagaimanapun juga harus ada pihak ketiga dan seterusnya untuk 
membantu memilih mana yang baik dan mana buruk, mana yang boleh dicontoh dan mana yang tidak. Adanya informasi yang menjelaskan cerita yang mereka baca, akan memudahkan anak dalam mencerna dan memahami cerita yang dibacanya. Perkenalkan mereka kepada bacaan anak-anak yang sesuai dengan alam pikiran mereka, karena ternyata membaca adalah kegiatan yang disukai di samping sekolah dan belajar. Terkadang di dalam bermain, mereka menyibukkan dan mengasyikkan diri mereka dengan membaca atau sekedar melihat berbagai buku bacaan. Mulai dari anak-anak yang baru mengenal gambar, sampai mereka yang sudah melek huruf. Dalam hal ini, komik merupakan pilihan yang tepat karena tidak hanya menyajikan cerita yang berupa tulisan tetapi disertai dengan ilustrasi gambar yang berupa gambaran tokohnya secara fisik, tempat terjadinya, dan juga situasi tertentu. Jadi, bagi anak-anak yang baru mengenal gambar, komik ini dapat digunakan. Tidak hanya tulisan yang berisi pesan, gambar pun dibuat karena ada pesan atau hal yang ingin disampaikan. Semua itu tergantung pada pemahaman pembaca yang disesuaikan dengan alam pikir dan daya imajinasi mereka masing-masing.

Ada anggapan bahwa membaca komik justru menimbulkan efek yang negatif pada diri anak karena mungkin anak jadi malas untuk membaca buku yang lain, lupa waktu, bahkan malas belajar, dan sebagainya. Padahal hal itu belum tentu benar, tergantung pada cara masing-masing orang tua dalam mengawasi dan mendampingi anaknya saat membaca buku-buku, khususnya bacaan sastra anak. Buktinya ada penelitian yang menyimpulkan bahwa hakikat bacaan anak-anak harus sesuai dengan hakikat alam hidup anak. Bacaan anak-anak harus mampu menyajikan cerita-cerita yang memberi umpan dan sekaligus merangsang fantasi anak-anak yang bersifat kreatif dan kongkret. Kemudian sifat bacaan anak-anak bertumpu dan bermula pada penyajian nilai dan himbauan tertentu. Nilai dan himbauan tersebut dianggap sebagai pedoman dan tingkah laku dalam alam kehidupan mereka.(Sarumpaet, 1977)

Oleh karena itu, membaca karya sastra anak (dalam hal ini komik) bukan merupakan suatu hal yang harus dilarang bagi anak, justru dapat dijadikan bahan pertimbangan bagi para orang tua untuk memberikan contohcontoh dalam menanamkan aspek-aspek yang mendukung proses pendidikan yang dilakukan di luar sekolah. Juga bagi para pengajar di sekolah-sekolah,

DIKSI, Vol.8 No.19 Januari 2001 
dapat dijadikan bahan ajar yang mampu melatih dan meningkatkan daya apresiasi dan imajinasi anak. Sedapat mungkin memberikan bacaan komik yang memang sesuai dengan alam kehidupan mereka dan tidak lupa adanya pengawasan oleh para orang tua dan para pengajar. Proses pembentukan dan pengembangan diri anak akan jauh lebih baik jika mereka melihat dan menemukan sendiri segala sesuatu yang berkaitan dengan kehidupan mereka dan tentunya ada sharing dari orang-orang yang lebih tahu, keluarga, masyarakat sekitar, dan juga para pengajarnya. Tidak diragukan bahwa daya kreasi imajinasi anak sudah mulai tinggi, hanya saja karena masih anak-anak belum ada batasannya. Oleh karena itu, dengan bantuan orang tua dan orangorang yang ada disekitarnya sebagai orang yang lebih tahu, diharapkan kemampuan anak dalam mencari dan menemukan hal-hal yang berkaitan dengan dirinya akan membawa anak menjadi pribadi yang baik. Berikan kebebasan kepada anak dalam membaca, biarkan mereka mengembangkan imajinasinya selama orang tua masih mendampinginya.

\section{F. Kesimpulan}

Karya sastra ternyata juga ikut berperan dalam proses pendidikan anak (membentuk kepribadian manusia). Begitu juga dengan komik sebagai bacaan sastra anak ternyata tidak hanya merupakan bacaan hiburan, akan tetapi juga dapat berperan sebagai aspek pendukung proses pendidikan anak, khususnya dalam pembentukan dan pengembangan kepribadian anak. Banyak nilai-nilai pendidikan yang dapat diperoleh dari sebuah komik yang nantinya dapat dijadikan bahan pertimbangan, tidak hanya dalam proses pendidikan di sekolah, tetapi juga di luar sekolah misalnya keluarga. Selain itu juga akan membantu melatih dan meningkatkan daya imajinasi dan apreasiasi anak ke arah yang lebih baik. Nilai-nilai pendidikan dalam komik secaragaris besar dapat diperoleh melalui percakapan antartokoh, tema, pemakaian bahasanya, dan penyajian bentuk gambaryang digunakan.

Dalam upaya merealisasikan komik ini sebagai salah satu wahana pendukung proses pendidikan anak, hendaknya ada dukungan dari para orang tua dan para pengajar di sekolah untuk lebih mengenalkan komik sebagai bacaan yang tidak lagi dilarang untuk dibaca. Memperkenalkan bacaan anak merupakan salah satu cara juga bagi orang tua dalam memperhatikan anak, dan membiarkan mereka membangun dan mengembangkan imajinasinya.

Komik sebagai Wahana...(Esti Swatika Sari) 
Selain itu juga akan membantu merekatkan hubungan anak dengan orang tua.

\section{DAFTAR PUSTAKA}

Franz, Kurt \& Benhard Meier. 1986. Membina Minat Baca. Bandung: Penerbit Remaja Karya CV.

Fujio, Fujiko F. 1998. Dora Emon.(Terjemahan Neneng Metty S) Jakarta: PT Elex Media Komputindo.

Hamzah, Amir \& Oejang Soewarjana. 1969. Ilmu Jiwa Kanak-kanak. Jilid I. Bandung: Penerbit GANACONV.

Nurdin, Muslim, dkk. 1993. Moral dan Kognisi Islam. Bandung: Alfabeta.

Nurgiyantoro, Burhan. 1995. Teori Pengkajian Fiksi. Yogyakarta: Gadjah Mada University Press.

Purbani, Widyastuti. 2000. "Beri Mereka Sayap", Makalah Seminar Sastra Anak, 11 Desember 2000. Yogyakarta. (tidak diterbitkan)

Sarumpaet, Riris K. 1977. Bacaan Anak-Anak: Suatu Penyelidikan Pendahuluan ke Dalam Hakikat, Sifat, dan Corak Bacaan Anak-Anak Serta Minat Anak Pada Bacaannya. Jakarta: Pustaka Jaya.

Sugiharti, Rahma. 1997. "Perilaku dan Kebiasaan Anak"; Prisma No.2 Februari, Tahun XXVI, hlm 39-47. Jakarta: PT Pustaka LP3ES.

Sugihastuti. 1996. Serba-serbi Cerita Anak. Yogyakarta: Pustaka Pelajar.

Suharianto. 1980. Pengantar Apresiasi Puisi. Solo: Widya Duta.

Tarigan, Henry Guntur. 1988. Prinsip-prinsip Dasar Sastra. Bandung: Angkasa.

Wellek, Rene dan Austin Warren. 1995. Teori Kesusastraan.(Terjemahan Melani Budianta) Jakarta: Gramedia Pustaka Utama. 